\title{
The Balance of Payments in Review
}

\section{Citation}

Cooper, Richard Newell. 1966. The balance of payments in review. Journal of Political Economy 74(4): 379-395.

\section{Published Version}

doi:10.1086/259180

\section{Permanent link}

http://nrs.harvard.edu/urn-3:HUL.InstRepos:11857764

\section{Terms of Use}

This article was downloaded from Harvard University's DASH repository, and is made available under the terms and conditions applicable to Other Posted Material, as set forth at http:// nrs.harvard.edu/urn-3:HUL.InstRepos:dash.current.terms-of-use\#LAA

\section{Share Your Story}

The Harvard community has made this article openly available.

Please share how this access benefits you. Submit a story.

Accessibility 


\title{
THE BALANCE OF PAYMENTS IN REVIEW
}

\author{
RICHARD N. COOPER* \\ Yale University
}

T HE balance-of-payments statistics of the United States have received a thorough examination at the hands of a distinguished committee chaired by Edward M. Bernstein in a report submitted to the United States government in the spring of 1965. ${ }^{1}$ The committee was asked to review "basic conceptual problems, problems of presentation and analysis, and technical statistical problems" pertaining to the balance of payments. The committee produced an excellent document, useful not only to government officials but also to all users of balance-of-payments statistics. Its Report follows several other valuable reports on U.S. government statistics that bear on measuring economic developments and interpreting them for the formulation of economic policy.

The National Bureau of Economic Research submitted a report on the national accounts in 1957 (NBER, 1957), the Stigler report on price statistics appeared in 1961 (NBER, 1961), and the Gordon report on unemployment statistics was released in 1962 (President's Committee To Appraise Employment and Unemployment, 1962). These excellent reports not only aid in pursuit of the tenet of American economics,

* This paper was completed while the author was on leave as Deputy Assistant Secretary of State for International Monetary Affairs. It does not, however, reflect the official views of the Department of State. I am grateful to C. Fred Bergsten and Ralph Bryant for helpful comments on a draft of this paper. Bryant has written a careful analysis of balance-of-payments concepts in a Ph.D. dissertation for Yale University.

${ }^{1}$ Review Committee for Balance of Payments Statistics (1965); hereinafter called the "Report." In addition to Bernstein, the Committee consisted of Richard E. Caves, George Garvy, Walter E. Hoadley, Harry G. Johnson, Peter B. Kenen, Roy L. Reierson, and Charles F. Schwartz, with John E. Reynolds as staff director. "science is measurement," but also rest on the correct presumption that sound policy requires accurate measurement.

General concern about the large and persistent deficit in the U.S. balance of payments since 1958 undoubtedly prompted the government to commission the Report. But it was especially prompted by two particular factors: first, by a feeling that the statistics we have are not good enough to provide the basis for refined policy decision, a weakness dramatized by the sharp shift in "errors and omissions" - one measure of the deficiencies in the statistics - from a credit of $\$ 0.5$ billion in 1959 to a debit of $\$ 0.8$ billion in 1960 ; and, second, by the lively controversy over the definition which the U.S. Department of Commerce has used to measure the "deficit" in the balance of payments and, hence, to determine in the public mind the size of the policy task facing U.S. authorities in correcting an imbalance in international payments.

The first part of this review describes and assesses the Report's findings with respect to the statistics themselves and its recommendations for improvement in the quality and presentation of the statistics. The second part considers the more controversial question of how "deficit" in the balance of payments should be defined. Finally, a third section offers some observations on the relationship of economic statistics to the formulation of economic policy, with special attention given to the balance of payments.

\section{THE STATISTICS}

The Report nowhere defines the accounts to which it offers so much thoughtful discussion. A country's balance of payments is typically defined as "a systematic record of the economic transactions during a given period between its residents and residents 
of the rest of the world" (International Monetary Fund, 1961, p. 2). These systematic balance-of-payments accounts involve double-entry bookkeeping, meaning that every transaction (being two-sided) is entered twice in the accounts. For example, exported goods (one entry) are traded for imports or for some form of financial claim on foreigners (the other entry).

This definition of balance of payments covers all economic transactions with foreigners, not merely the transactions which take place through the foreign-exchange market. Especially where they apply to important international banking and investing nations, such as Britain and the United States, the accounts include many transactions denominated in the home currency and involving no use of foreign exchange at all.

The convention of entering each transaction twice poses a difficulty when goods or assets are given away or are received as gifts. This difficulty is overcome by making an artificial entry for "unilateral transfers," the counterpart (with opposite sign) of the unrequited exports or flow of funds. Inevitable deficiencies in the reporting system mean that total recorded receipts will differ from total recorded payments, giving rise to "errors and omissions," sometimes less accurately called "unrecorded transactions" or, by the British, simply the "balancing item." As already noted, a sharp shift in these errors and omissions in 1960 is partly responsible for the current interest in the quality of U.S. balance-of-payments data.

Putting together a balance-of-payments account raises questions about how to define or identify international transactions, how to collect accurately data reflecting thousands of transactions by businesses and individuals, how to value transactions that do not go through the marketplace and, finally, how to classify balance-of-payments data in ways most useful to their users: questions of residency, coverage, valuation, and classification.

The Report does not give an exhaustive treatment of these issues. It does not purport to be a complete handbook for balance- of-payments statistics and indeed strongly urges updating the latest (1952) detailed official commentary on the collection and quality of the statistics. But the Report does give helpful glimpses into all of these problems. Its description of how data are collected and its extensive recommendations for improvements will be useful both to the general economist and as a starting point to the researcher. The following paragraphs touch only a few of the characteristics of U.S. balance-of-payments statistics to illustrate how these issues arise in practice; most are taken from the Report, but one or two are oddly omitted there.

1. The Report is weaker on the question of residency than it is on the others. A number of exceptions to the resident-non-resident distinction underlie the data. Washington employees of the Agency for International Development and the Peace Corps will be amused or alarmed, depending on their temperament, to learn that their salaries and other domestic administrative costs enter the U.S. balance of paymentstwice, in fact; first as an "export of services" and then as a "government grant to foreigners." The balance-of-payments statistics in effect treat these civil servants as lobbyists for foreigners paid by the U.S. taxpayer. It is difficult to see why these expenditures should be regarded as an international transaction in view of the high foreign-policy value the United States places on the activities of both of these agencies; or, to go to the other extreme, why all or part of the domestic expenditures of the Department of State, the Foreign Agricultural Service, the National Institutes of Health or, indeed, the Ford and Rockefeller Foundations are not also considered international transactions. The Report's indorsement of the current practice is especially strange in view of the emphasis it later places on maintaining as much international symmetry as possible in national balanceof-payments accounts. Certainly no other countries consider these "exports" as imports.

Gold purchases from Treasury stocks by 
domestic users are also counted as international transactions, and it is a pity that the Report does not recommend-indeed does not even discuss - this anomaly in the accounts. In 1964 U.S. users purchased no less than $\$ 89$ million in gold (out of total gold "losses" of only $\$ 125$ million!) from the American monetary authorities. These purchases are entered fictitiously in the payments accounts as merchandise imports which are "paid for" by a decline in the monetary gold stock. It can be argued, of course, that the United States is a net consumer of gold and that gold would have had to be imported if it could not be purchased from the U.S. Treasury. But this same argument applies equally to consumption out of any stocks of imported goods; yet we do not treat disposals of aluminum or copper from the national stockpile as imports. We should let gold take its place with other nonferrous metals in the balance-of-payments accounts. ${ }^{2}$ Once again this treatment of gold lacks symmetry, since a domestic gold purchase from the Treasury is an "import" that

${ }^{2} \mathrm{~A}$ second rationale for entering domestic gold transactions in the balance-of-payments accounts is that it links international transactions (measuring flows) with changes in stocks of reserve assets. But we do not follow a similar practice with respect to capital transactions in the balance of payments; instead, specialstock adjustments (for example, arising from changes in exchange rates or business defaults) are made in reconciling international capital movements with changes in the country's international asset position.

A third possible rationale is that an addition to monetary gold stocks from domestic production generates income but does not represent a use of income. In this respect it is like an export surplus, which indicates an excess of total domestic production over total domestic expenditure. But the same problem arises with other additions to inventories, and domestic gold transactions could be entered in the national accounts as inventory changes rather than as international transactions.

In fairness, it should be added that in accepting the entry of domestic gold transactions in the balance-of-payments accounts the Report is following current practice the world over, a practice sanctioned by the International Monetary Fund (IMF). But it is a practice that needs re-examination in a world in which central bank decisions, not changes in the gold stock, govern the supply of money in most countries. no other country exports during the same period of time.

On one matter of residency the Report does urge a much-needed change. It argues, following IMF recommendations, that earnings on foreign investments reinvested abroad should be treated as international transactions, to be entered twice into the balance-of-payments accounts, both as earnings on foreign investments and as capital outflow. At present this treatment is applied to foreign branches of American firms but not to foreign subsidiaries, thus introducing an artificial distinction into the statistics based less on economic logic than on our tax laws, which induce the extractive industries to invest abroad in branch form in order to benefit from depletion allowances. This practice understates both investment earnings and capital outflow. Since data on reinvested earnings are not and cannot easily be collected on a quarterly basis, the Report recommends the second best solution of including reinvested earnings as an addendum to the main statistics.

2. With respect to coverage the United States has the best published balance-ofpayments statistics in the world, in most cases by a very substantial margin. ${ }^{3}$ Yet there are serious gaps and imperfections in coverage despite this general superiority over the data of other countries. For example, U.S. receipts for ocean freight services rendered to foreigners are estimated from coverage amounting to only 63 per cent of the estimated total. Travel expenditures are based on a mail questionnaire to which nearly 50 per cent of the solicited Americans but only 2 per cent of the solicited foreigners responded. Exports to Canada by truck are recorded on an equally hit-or-miss basis. Information on direct investment is based on reports from 900 corporations, out of a total of 2,800 American corporations known to have had invest-

${ }^{3}$ It is noteworthy that in the recent controversy over American investment in Europe the officials of the European Common Market had to rely on American data to document their case; European data on direct foreign investment were virtually nonexistent. 
ments abroad in 1957 and a much larger (but unknown) number today.

Low sampling coverage is not a weakness per se, but we have little indication of the sampling bias. The Report recommends more frequent use of benchmarks, most urgently required for U.S. investment abroad. Many of the errors, of course, cancel each other in recording the over-all balance-of-payments position; but the remaining net errors and omissions have been substantial and have swung widely from year to year, and the errors distort particular categories of transactions substantially more then they distort the total.

3. Not all errors in the statistics are due to deficiency in coverage; some are due to deficiencies in valuation. For example, imports of coal-tar products are entered at their American selling price, because that is the price on which customs duties must be collected. The error here is small because imports are kept so low by this highly protective device. But transfers of agricultural products under Titles II and III of Public Law 480 are exaggerated by over $\$ 100$ million by valuing shipments at the price the Commodity Credit Corporation pays the American farmer rather than at world market prices. ${ }^{4}$ All non-market transactions such as these grants pose difficulties in valuation. In addition, intracorporate pricing practices may cause either under- or overstatement of imports and exports and may therefore distort the recorded figures on trade, investment earnings, and investment outflows. Investment abroad that is "paid for" with patent rights or technical know-howsurprisingly overlooked by the Report despite its allegedly growing importance-also distorts the figures by understating U.S. receipts.

Data collecting is no area in which to counsel perfection. The Report wisely avoids that in favor of numerous useful and prac-

${ }^{4}$ Curiously enough, this misvaluation has apparently been corrected for the exports themselves, but not for the "equivalent" entry under unilateral transfers. This difference in treatment gives rise to a positive error in the "errors and omissions." tical recommendations for improving our statistics. It rightly asserts that the U.S. balance-of-payments problem warrants the additional budgetary resources which would be required.

4. Finally, the problem of classification remains even after all the data are collected. The mass of information must be organized in some way. Two broad principles usually vie for attention when it comes to classifying balance-of-payments transactions: they can be organized by transactor or by type of transaction. Transactions are often divided according to whether the initiator was a private citizen or a government official, or according to whether or not it was a bank; and capital transactions are almost always distinguished from current transactions. ${ }^{5}$ Most schemes involve some combination of these two. As we will see in the next section, however, classification schemes often falter in an attempt to classify transactions according to the motives of the transactor.

A major achievement of the Report is a greatly expanded and integrated set of accounts, which offers detailed raw material for reclassification by other users of the statistics, all provided in mutually consistent form and keyed to its summary table (p. 128). The U.S. government of course publishes much detail today, but users often find it impossible to reconcile the various sources of information or even to discover the reasons for apparent discrepancies among data published by the Commerce Department, the Treasury Department, and the Federal Reserve System. The Report helpfully provides a complete set of illustrative tables (pp. 128-45) with data for

${ }^{5}$ We collect balance-of-payments data on two quite different principles. The value of current transactions (for example, trade or travel expenditures) is cumulated during some specified period of time. In contrast, capital transactions are usually recorded by measuring the change in net claims on or liabilities to foreigners between two points of time; gross international capital transactions during the intervening period may have been much larger than the change in net claims or liabilities suggests. As a result, the system of classification for capital transactions influences very much the size of the recorded "flows." 
1963, some of them published for the first time $^{5 \mathrm{a}} \mathrm{It}$ also makes detailed recommendations for a yearbook of balance-of-payments statistics, both to pull together in one place all statistics related to the balance of payments and to contain notes on methodology and changes in collection, coverage, or processing of the statistics. ${ }^{6}$

\section{DEFINITION OF THE DEFICIT}

Putting together a complete and accurate set of balance-of-payments accounts is difficult enough. Interpreting them correctly raises an entirely new set of problems. And interpreting them satisfactorily in the stub of a table alone is quite impossible. The Report explicitly rejects the notion that officials or the public must view the balance of payments "in terms of a single summary concept, surplus or deficit" (p. 101). But it concedes that "the desire of busy people for clear-cut summaries of complex eco-

5a The June, 1966, issue of the Survey of Current Business incorporates a number of these recommended improvements in presentation and offers extensive data for previous years.

${ }^{6}$ The Report makes numerous other recommendations on presentation. Among them: $(a)$ to restore the notion of "current account" to U.S. balance-ofpayments statistics and to link this directly to the external sector in the national income accounts (at present some international transactions appear in the government sector of the national accounts rather than in the external sector); $(b)$ to avoid "netting" transactions, a growing practice in recent years, especially in the government transactions, which obscures important changes in the underlying gross transactions; $(c)$ to use "receipts" and "payments" instead of "credits" and "debits" in the published accounts, a minor but pedagogically useful change.

The Report unfortunately omits discussion of the question whether imports should be recorded on an f.o.b. basis or a c.i.f. basis. Most countries record imports on a c.i.f. basis, and it has been occasionally suggested that the United States should do the same. It would have been useful for the Report to array the arguments why the existing U.S. system is preferable to that used by the United Kingdom and other countries: recording imports c.i.f. not only buries useful information on shipping and insurance, but also erroneously enters some purely domestic transactions in the international accounts, especially misleading for major shipping nations. nomic situations is understandable," and it suggests that this desire can be met through an integrated set of detailed accounts, already discussed, and through a single concept of surplus or deficit which "can be broadly useful as a starting point for analysis" (p. 101). It is the attempt to specify such a single concept that has given rise to extensive professional controversy about the appropriate measurement of imbalance in international payments.

Defining "surplus" or "deficit" in international payments entails some systematic exclusion of certain credits or debits from a set of accounts which must always "balance" when taken as a whole. What is the basis for any such exclusion, for drawing a line through the accounts? The theoretical literature on balance-of-payments concepts usually draws a distinction between international transactions that are "autonomous" and those that are "accommodating" or "compensatory." The former are all transactions that are undertaken independently of the condition of the balance of payments itself, while the latter are transactions that are the direct consequence of the sum of autonomous transactions (see Meade, 1951, chap. iii; International Monetary Fund, 1949, pp. 4-24). According to this distinction, the surplus or deficit is defined as the sum of the autonomous transactions; it is these that determine the amount of residual "financing" that is required.

In its first efforts to classify national balance-of-payments accounts, the IMF adopted a definition of the deficit that involved "official compensatory financing," defined circularly as "the financing undertaken by the monetary authorities to provide exchange to cover a surplus or deficit in the rest of the balance of payments"(IMF, 1949, p. 5). This financing was identified as changes in reserves, changes in liabilities to foreign monetary institutions, and official grants and loans undertaken primarily for balance-of-payments reasons. This definition was used for several years as the principal organizing concept in the Fund's Bal- 
ance of Payments Yearbooks. It was never accepted universally by the Fund staff, however, and it was finally dropped in 1954 on two grounds. First, which transactions were compensatory and which were not often required a Solomon-like judgment regarding the ultimate motives of the monetary authorities, a judgment that was inevitably subjective and led to differences in classification among equally honest and competent observers. Second, the concept was not symmetrical. Official compensatory financing for one country might have as its counterpart a strictly "autonomous" transaction in another, as when the monetary authorities of one country borrow in the private financial market of another. Thus there could be deficits with no surpluses.

It is the identification of motive that has proved most troublesome. The data actually collected can be grouped into autonomous and accommodating transactions only if motives for the transactions are closely related to certain transactors or to certain types of transactions that are observable. Much of the longstanding debate over the appropriate measure of surplus or deficit revolves around differing beliefs about this correlation between motive and observed transactions. ${ }^{7}$ More recently, the debate has been equally concerned with what the surplus or deficit is supposed to measure in the first place.

During the period 1960-64 the United States officially used no fewer than three different concepts of the "deficit," and in December, 1965, it introduced still a fourth concept, based largely on the recommendations of the Bernstein Report.

The first of these concepts is the so-called balance on basic transactions, or, more accurately, the balance on goods, services, transfers, and long-term capital account (line $\mathrm{C}$ in Table 1 ). This summary measure

\footnotetext{
${ }^{7}$ The difficulty is complicated by the fact that profit-motivated transactions in the private sector may be heavily influenced by public policy geared to the balance of payments, e.g., changes in monetary policy. Should such transactions be regarded as "autonomous" or "accommodating"?
}

of the U.S. balance-of-payments position was used in official statistics in the late 1940's and was reintroduced in 1961. It is also the concept used by a number of other countries. It represents an attempt to measure the underlying trends, abstracting from such "volatile" transactions as shortterm capital movements and errors and omissions (changes in which are assumed to be largely unrecorded short-term capital movements).

A second and more convincing rationale has recently been advanced for the "basicbalance" concept. It is said to include below the line those transactions that respond most quickly and with greatest certainty to changes in government policy and in particular to changes in monetary policy. ${ }^{8}$ With major currencies now convertible and exchange controls greatly relaxed, monetary authorities can allegedly induce a substantial inflow of short-term funds (or reduce an outflow that had been taking place) simply by raising interest rates or by depressing forward exchange rates. This sensitivity to monetary measures permits government action to influence these private transactions at will. Thus while the transactions themselves are motivated by profit considerations, their profitability is influenced in turn by official action and thus by balanceof-payments policy. To the extent that the classification of transactions as policysensitive is correct, transactions below the

${ }^{8}$ For a clear statement of this view see Lary (1963), esp. Appendix A. Lary was chief of the Balance of Payments Division in the Department of Commerce during the 1940's and chaired a government task force that urged the reintroduction of the "basic-balance" concept in 1961. Lary wrote before the problem of treating military prepayments and non-convertible Roosa bonds arose, so we cannot be sure where he would have entered them, although his treatment of debt prepayments suggests he would have included them in line 5 of Table 1 , as is done here. Line $C$ in Table 1 corresponds to the "balance on goods and services, government assistance, and long-term capital accounts" that appears in Table 2 of the Commerce Department's Survey of Current Business (see, for example, the issue for June, 1965, p. 14). This is the legacy of Lary's task force. 
line can be said to be "accommodating" to the requirements of the "autonomous" transactions above the line. But unfortunately the sensitivity of various international transactions to monetary policy varies along a continuum, so any dichotomy into "policy-sensitive" and "not policy-sensitive" is necessarily artificial; and over time
$\mathrm{D}$ in Table 1). It places below the line changes in U.S. monetary reserves plus changes in U.S. liquid liabilities to all foreigners, and differs from the "basic" balance by entering short-term capital outflows from the United States, foreign commercial credits, and errors and omissions above the line. The liquidity concept has been used in

TABLE 1

VARious Balances in The U.S. Balance OF Payments With Data For $1964^{\mathrm{a}}$

\begin{tabular}{|c|c|c|}
\hline \multirow[b]{2}{*}{ 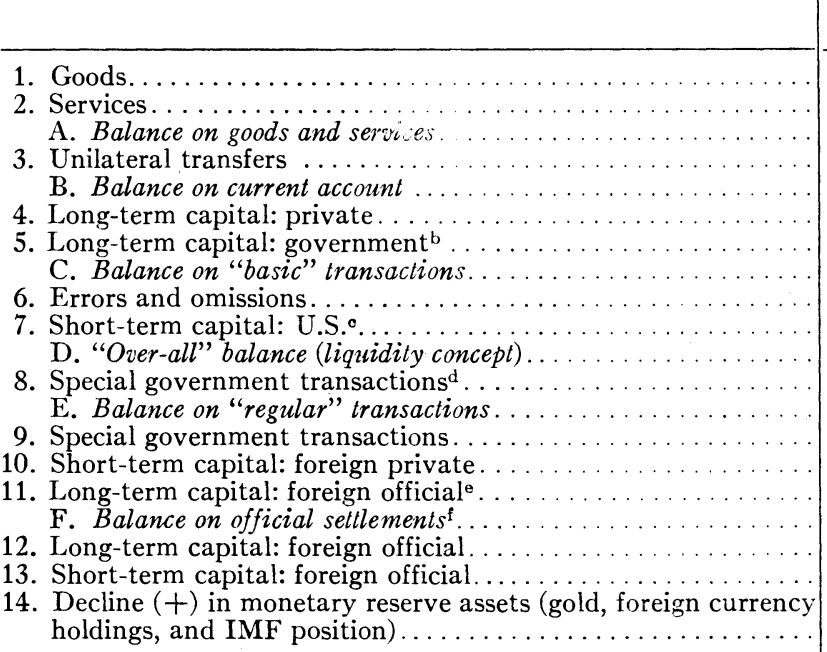 } & \multicolumn{2}{|c|}{ Billions of Dollars } \\
\hline & $\begin{array}{l}+6.7 \\
+1.8 \\
-2.8 \\
-4.3 \\
-1.2 \\
-1.0 \\
-2.0 \\
-0.3 \\
+0.3 \\
+1.6 \\
-0.3 \\
+0.3 \\
+1.1 \\
+0.2\end{array}$ & $\begin{array}{l}+8.5 \\
+5.7\end{array}$ \\
\hline
\end{tabular}

\footnotetext{
NoTE: Components do not always add to the various balances because of rounding.

a Data differ somewhat from those in the Bernstein Report due to subsequent revisions.

b Includes "special government transactions," deducted in line 8, added again in line 9. These comprise prepayments on government loans and advance payments for military exports.

c Includes foreign commercial credits, that is, changes in short-term liabilities to foreigners reported by nonfinancial concerns and brokerage firms.

d Net receipts from "special" government transactions must be deducted to compute a balance on "reguar" transactions. See note b. They are entered again with their correct balance-of-payments sign in line 9.

- Certain long-term lending by foreign monetary authorities-their net purchases of non-convertible Roosa bonds and long-term certificates of deposit-must be deducted here to compute a balance on official settlements. These securities are not considered "liquid" for purposes of the liquidity balance in line D. They are entered with their correct balance-of-payments sign in lines 4 and 5 and again in line 12 .

I Differs conceptually from the balance struck by the Bernstein report, which entered advance debt repayments below the line but certain long-term official lending above the line. These transactions roughly offset one another in 1964. The balance here is that adopted by the U.S. government in June 1966.
}

both the sensitivity of transactions to policy and the policy instruments themselves are likely to change, so the aptness of any particular dichotomy will probably be shortlived.

A second measure of the balance-ofpayments position is the so-called over-all balance, which should more properly be called the change in liquidity position (line official statistics in approximately its present form since late 1955 (before that time all changes in foreign assets through transactions with the United States were entered below the line, including long-term assets). Its staunchest defender is Walther Lederer, chief of the Department of Commerce's Balance of Payments Division and the offcial responsible for compiling the U.S. 
balance-of-payments statistics. Lederer argues that the balance of payments should reflect the ability of the monetary authorities to defend the exchange value of the dollar and that "their capability depends upon their liquid resources and the liquid claims which can be exercised against these resources." 9 The liquid resources include gold, official holdings of foreign convertible currencies, and automatic drawing rights on the IMF. The debate centers on measurement of the potential liquid claims against which the U.S. monetary authorities might have to use these assets to defend the dollar. The Department of Commerce includes all liquid liabilities to foreigners. ${ }^{10}$ Others contend, first, that many of the "liquid liabilities" to foreigners are in fact far less likely to be involved in a run on the dollar than many other assets, including most importantly the liquid assets held by residents in the United States; and, second, that many of the recorded U.S. liquid liabilities are really locked in, representing minimum working balances, compensating balances that must be held against U.S. loans to foreigners, balances required to maintain future lines of credit, and the like. Thus the Department of Commerce concept includes either too little or too much to be useful as a measure of the potential claims against U.S. reserve assets. ${ }^{11}$

Moreover, measuring changes in the "liquidity position," while interesting and important, may not offer the best single summary of the balance-of-payments position as a whole, particularly since a steady growth in foreign balances of the world's major currency is to be expected, while calling this growth a "deficit" leaves the impli-

9 "Measuring the Balance of Payments" (1962), quoted in Lary (1963), p. 142; see also Lederer (1963).

10 "Liquid liabilities" here mean short-term liabilities to foreigners other than commercial credits and brokers' balances plus foreign holdings of marketable U.S. government bonds and notes plus those medium-term non-marketable U.S. Treasury notes which are convertible into cash on short notice. cation that it should be eliminated. This is a topic to which we will return below.

The Department of Commerce's concern with the country's liquidity position was cast into doubt when in 1963 it introduced a new "balance on regular types of transactions" which subsequently became the basis for official statements about the balance of payments (line $\mathrm{E}$ in Table 1). This concept starts with the liquidity concept of the deficit but in addition enters below the line, that is, fails to count as receipts, certain transactions that were specifically designed to reduce foreign liquid dollar holdings, including advance repayments of debts owed to the United States, advance payments on military orders, and purchases of "Roosa bonds." 12 This separate identifica-

${ }^{11}$ In the mid-1950's the "liquidity concept" might have had greater validity on the grounds that foreign private holdings of dollars merely represented foreign reserves in disguise, since under the extensive exchange control then prevailing they could be readily mobilized by foreign monetary authorities. But these controls have gradually been relaxed in most major countries, so that foreign banks and businesses have been increasingly free to invest abroad at times and in amounts of their own choosing. Their dollar holdings represent assets held for profit or for convenience, influenced only indirectly (as through monetary or forward exchange policy) by the monetary authorities. Thus the liquidity concept was said to introduce an unwarranted "asymmetry" into the U.S. accounts, by entering above the line private U.S. short-term capital outflows while entering below the line essentially similar private foreign short-term capital inflows. This asymmetry has given the U.S. balance a strong negative bias, exaggerating the size of U.S. deficits on the liquidity basis.

On the other hand, an unknown volume of official reserves today is held in foreign commercial banks in the Euro-dollar market, and these holdings are not recorded as U.S. liquid liabilities to foreign monetary authorities.

${ }^{12}$ Medium-term non-marketable notes issued by the U.S. Treasury to foreign governments and central banks. The first issue was to the Swiss Confederation in 1962 . They are typically denominated in foreign currencies and therefore eliminate the exchange risk entailed in holding dollars. Inaugurated by then-Under-Secretary of the Treasury for Monetary Affairs, Robert V. Roosa, in 1962, these bonds totaled $\$ 1.4$ billion by the end of 1964 .

The Department of Commerce began to identify 
tion of "special government transactions" resurrects the old IMF concept of "compensatory finance": transactions that are deliberately designed to finance a deficit that arises from all other, autonomous, transactions. The result was an unsatisfactory hybrid, based partly on transactions by type required for the liquidity concept (which its supporters admit includes some "autonomous" transactions), and partly on an assessment of motives required for the autonomous-accommodating distinction.

The Bernstein committee rejects all three of these balance-of-payments concepts in favor of a fourth, "official settlements" (line $\mathrm{F}$ in Table 1). The official-settlements balance enters below the line only changes in U.S. monetary reserves, changes in the U.S. position at the IMF, changes in total U.S. liabilities to foreign official monetary institutions, and prepayments of foreign debt to the U.S. government.

The Report turns to this concept as much out of dissatisfaction with the alternatives as on its positive merits. In justifying its choice of measurement, the Report states:

In the Committee's view, the main purpose of a summary indicator of the balance of payments position should be to indicate the extent of any disequilibrium that may exist in the country's international transactions. We wish, essentially, to measure the gap between the normal supply of and demand for foreign exchange-a gap which the monetary authorities, here and abroad, must fill by adding to, or drawing down, their reserve assets if exchange rates are to be held stable. The United States has a deficit which cannot be indefinitely continued, and which must therefore be corrected, if its reserve assets are declining and/or if the claims of foreign monetary authorities on the United States are rising. This seems to us the only situation in which it can usefully be said that there is a U.S. payments deficit. If, instead, only foreign private holders are adding to their assets in this country, this does not necessarily represent a

special government transactions in 1961, but not to exclude them from above-the-line receipts until 1963. position of disequilibrium, and to say there is an overall deficit, as one would using the "liquidity" concept, has no precise meaning.

... The size of these transactions in international reserves provides the best available measure of the market intervention that has been necessary, of the gaps that have had to be filled, and hence of payments disequilibria [pp. 109-10].

In measuring the "deficit" the committee thus starts from a fundamentally different conception than does Lederer with his liquidity concept. The latter concept is alleged to measure changes in the U.S. liquidity position-quick assets less quick liabilities-vis-à-vis foreigners, while the Bernstein committee wants "to measure the gap between the normal supply of and demand for foreign exchange" under stable exchange rates.

Unfortunately, to turn the committee's damning words on its own concept, the term "normal supply and demand" has no precise meaning. This is true for any currency, but it is particularly true for a reserve currency where, on the one hand, both private and official bodies require holdings of the currency for transactions and precautionary purposes ("normal" demand?) and, on the other hand, both private banks and monetary authorities may experience a rise or a fall in their holdings of the currency as a result of discrepancies between "normal" demand and supply. For example, German and Italian central banks have used special swap facilities to encourage commercial banks to hold far more dollars than they otherwise would. On occasion such swaps have exceeded $\$ 1$ billion.

In focusing on "normal" supply and demand the Report recommends entering below the line intergovernmental capital transactions that are "specifically arranged for the purpose of financing an international payments surplus or deficit" (p. 119) and that are "large and non-recurrent in nature." It finds that of the special government transactions since 1960 , only advance debt repayments fit these restrictions. In deciding whether to place foreign credits 
to the United States above or below the line the Report says that the "key test" is "whether or not the foreign holder of an asset in the United States is a monetary authority" (p. 109). On these grounds it places all Roosa bonds below the line regardless of the presence or absence of a convertibility clause, with one curious exception. Bonds sold in 1962-64 to the Swiss Confederation "as an investment of budget surpluses" are considered ordinary capital inflows, entered above the line. But bonds sold in 1964 to the government of Canada in connection with Columbia River power development are entered below the line as a monetary transaction. When is a government a "monetary authority" and when not?

Separating selected government transactions for special treatment can give rise to some vexing problms. The transactions so separated in the official accounts in recent years have been advance repayment of U.S. government loans (mostly made to Europe immediately following World War II), advance payments against future delivery of military equipment, and receipts from Roosa bonds. The Report rejects entering advance payments on military orders (patently made for balance-of-payments reasons by Germany to the United States in 1962-64) below the line in part because deliveries may catch up with these payments even before the balance-of-payments deficit has been corrected. It may also have been influenced by the fact that the resulting U.S. liabilities were to a non-monetary authority. Having made that judgment, the Report illogically fails to treat advance government-to-government debt repayments as above-the-line transactions on the same grounds, namely, that below-the-line treatment would result in inconsistencies over time. Such prepayments eliminate for all time the "normal receipts" from subsequent scheduled repayments. In both cases the deficit country is borrowing against the future to cover a deficit in the present. The Report acknowledges the difficulty created by its proposed treatment of debt prepay- ments, but it uncharacteristically deals with it in a shoulder-shrugging "one must simply remain alert to this fact" (p. 120).

The Report fails to mention the nonpayment by Britain of principal and interest due in 1964 on the Anglo-American Loana sum of $\$ 138$ million-even though this "transaction" involved exactly the same kind of consideration as the advance debt repayments and it might therefore logically have been entered in the U.S. accounts both above the line as a normal receipt and below the line as a "special transaction" involving a loan to Britain. The committee apparently balked at carrying the logic of its position so far as to require two entries for a nontransaction! In implementing the Report's recommendations the U.S. government fortunately abandoned any attempt to record special government transactions below the line; the "official settlements" concept actually adopted therefore differs somewhat from that recommended by the Bernstein committee. ${ }^{13}$

As is clear from the above discussion, there is an imposing array of concepts for defining a country's payments surplus or deficit. That there are so many and that the debate over them has lasted so long reflect a difficulty inherent in measuring a country's payments position. The task is elusive because the accounting framework of measurement is essentially classificatory, not analytical. It represents an ex post grouping of international transactions by type or by transactor (current-capital, government-private, etc.). But no ex post observation can measure with regularity and with exactness "the gaps that have had to be filled" since we cannot observe what those gaps are. The notion of disequilibrium, of gaps to be filled, is an ex ante one, based on an analytical concept like "autonomous" transactions-autonomous in the sense that they would take place under existing poli-

${ }^{13}$ In computing its official settlements balance the government decided to enter above the line not only military prepayments but also all advance payments on government debt. All Roosa bonds are to be entered below the line, including some bonds which are not convertible and hence are not "liquid." 
cies and without regard to the state of the balance of payments itself. Analytically, motive is very important, even though it cannot usually be accurately recorded.

The degree of disequilibrium in a country's external position depends closely on the state of the country's economy and on that in the rest of the world-on levels and rates of growth in income, on levels and rates of change in prices, on exchange rates, on relative interest rates and how they are moving and how they are expected to move. All these economic variables and others are subject to influence by government policies; and government policies may change because of the requirements of the balance of payments. The "gap to be filled" is thus a variable one, depending on economic policies at home and abroad.

Nurkse (1945) suggested long ago that "disequilibrium" in the balance of payments under fixed exchange rates should be defined as the foreign-exchange gap in autonomous transactions resulting when economic policies are set to achieve major economic objectives, namely, full employment, price stability, absence of direct controls over current and capital transactions. This definition thus has an important normative dimension. It attempts to specify the economic policies that should obtain before imbalances in payments can be properly measured and is thus designed to eliminate one source of ambiguity about the gap to be filled. (It is clear from recent focus on the "mix" of policies that Nurkse's attempt to fix economic policies by specifying objectives cannot be fully successful.

There is, however, a further problem with the notion of a gap to be filled. Government policy can often alter this gap superficially, for example by inducing a reflow of shortterm assets from abroad or by precipitating a rundown in stocks of imported goods. Sales from the U.S. copper stockpile may be as helpful in "filling a gap" as sales from its gold stockpile. Similarly, a recall of outstanding claims on foreigners can temporarily reduce the deficit-or finance it, depending on the definition used-whereas only a change in flows of new savings much affects the value of "equilibrium." Yet shifts in stocks of outstanding claims are indistinguishable in practice from changes in flows of new saving. No definition of the deficit could in practice include one component above the line and the other component below.

Just as private and official transactions may be the result of official moves to correct imbalance in international paymentsand hence are not "autonomous" of the state of the balance of payments-official transactions may take place quite independently of the balance of payments in the current period. For example, Canada in 1962 borrowed $\$ 250$ million for the stated purpose of adding to its foreign-exchange reserves, and Denmark in 1965 borrowed $\$ 25$ million for the same reason. Many central banks probably have some "autonomous" demand for reserves just as commercial banks do. To the extent that this is so, offcial transactions are not merely gap-filling. ${ }^{14}$

The Report has not overcome this basic hurdle. It may be right in suggesting that the official settlements basis is "the best available measure" of the gap to be filledif a single measure must be chosen. But because of the inherent fuzziness of the concept of a "gap," the Report should have resisted more strongly the notion that any one measure is appropriate; it should have given more weight to the view that those who do not understand the important differences and variations among concepts have no right to have placed in their hands for use a single concept "with no ifs, buts, or maybes," on the same principle that children should not be given real guns until they are taught how to use them properly. ${ }^{15}$

14 This brief sketch obviously does no justice to the complexities involved in specifying and identifying "autonomous" transactions. For example, is a balance-of-payments support loan from one country to another autonomous or compensatory when the first country is in bilateral surplus with the borrowing country but in deficit with the world as a whole?

${ }^{15}$ Ralph Bryant has likened interpreting balanceof-payments developments to flying an airplane. No pilot would want to rely on one instrument alone 
This is a harsh and arrogant view, and obviously could be carried to the unwarranted extreme of denying publication of any statistics on the grounds that they are all imperfect and subject to misinterpretation or deliberate misuse. But it is in a sense even more arrogant to believe that a single concept can be established by experts and officials to serve satisfactorily all and sundry needs. The committee obviously agrees, and it is a pity therefore-especially in light of the close but unwarranted link of measured deficits to policy targets, a topic to be taken up below - that it did not give more sympathetic hearing to the view that no official deficit should be published or that several different concepts should be published side by side, thereby seeding enough confusion to indicate that it is a complicated matter. ${ }^{16}$

\section{OFFICIAL STATISTICS AND POLICY TARGETS}

The language we use to describe economic phenomena contains certain normative implications regarding policy targets. We speak of an "unfavorable" balance of trade or payments. A country's balance of payments should obviously "balance"; "disequilibrium" should be transformed into "equilibrium." By what means and how rapidly balance should be restored are open to debate, but not the objective itself-so the language dictates.

The measurement of the balance-of-payments deficit thus influences the concern that even relatively sophisticated officials and members of the public-both foreign and domestic-show for the balance of payments. Indeed, insisting on a single measure can have little other purpose than to generate or allay such public concern.

to gauge the direction and stability of his flight; he relies on his entire panel of instruments.

${ }^{16}$ Apparently in the spirit of compromise, the government adopted a slightly modified version of the Report's official settlements concept but also retained the liquidity definition. In December, 1965, the Survey of Current Business began to publish two measures of the U.S. deficit, one based on liquidity and one based on official settlements.
To the extent that a measured deficit defines the policy task - the size of the correction which must be made to "restore equilibrium"-the method of measurement ceases to be a purely technical matter and becomes crucial in the formulation of economic policy. Accurate measurement is important, of course, not only for the balance of payments but also for the other targets of economic policy: full employment, price stability, the rate of economic growth, and so on. But there is a critical difference in this instance between those targets that involve "balance" or "stability" and those that do not. Achieving "balance" or "stability" involves setting some number-the measure of the target variable-equal to zero. Where balance or stability is not involved, the numerical target can be positive or negative, and which particular number becomes the target will be reached pragmatically, not on a priori grounds. Thus the quantitative target will have been adjusted for errors in concept and measurement, provided that these errors do not vary rapidly over time.

Examples of the pragmatic character of non-zero policy targets are provided by stated U.S. objectives toward the rate of unemployment and the rate of economic growth. In 1961 the U.S. government established 4 per cent of the labor force as the interim target to which U.S. unemployment should be lowered. At roughly the same time, the figure of 4.8 per cent per annum was held out as a reasonable target for growth of the American economy during the decade of the 1960's (Economic Report of the President, 1962, chap. ii). There is nothing magic in either of these numbers. They were determined by experienced economic practitioners as what could reasonably be expected of the American economy with appropriate policies, in terms of the way the official U.S. statistics measure unemployment rates and changes in real gross national product. If economic policy-makers had decided to specify a growth target in terms of industrial production, the quantitative target would presumably have been different from that for real GNP, reflecting not only the differences 
in the things being measured but also the foibles of the measuring rods. Policy targets should be neither so easy as to offer no challenge nor so difficult as to be unattainable. If the chosen numerical targets appear too easy or too difficult after some length of time, they will presumably be changed accordingly. ${ }^{17}$

When the target involves setting some measured entity equal to zero, this built-in pragmatic approach cannot operate. Thus from a policy point of view much greater care is required in measuring such quantities as the balance-of-payments position or the rate of change in prices than unemployment and economic growth, for the "natural" policy target in each of the former cases involves setting the measured quantity equal to zero. There is a serious danger that defects of measurement will be transformed into defects in policy. ${ }^{18}$

This argument may benefit from some slight formalization. For concreteness it can be couched in terms of the balance of payments, but a similar argument applies to other policy targets.

Define $E$ as the ex ante disequilibrium on "autonomous" transactions in a country's

${ }_{17}$ The growth target was in fact modified when the demographic projections on which it was based were adjusted.

The choice of unemployment rate appropriate to policy formulation has given rise to an interesting but not very meaningful debate. Some observers have argued that the target should concern married men, not all persons in the labor force. Others contend it should include an adjustment for part-time employment. But in fact many reasonable measurements of unemployment are highly correlated, and setting a target of 4 per cent for total unemployment implies a target rate of about 2 per cent for married men. Given the way the U.S. labor market works and the characteristics of the measurements, these two targets mean roughly the same thing, even though the numbers differ.

${ }^{18}$ The same danger exists with Sir William Beveridge's famous formulation of the appropriate target for a full-employment society: setting the level of unemployment equal to the number of unfilled vacancies. Such a policy target would have placed encr mous responsibility on the shoulders of government statisticians. balance of payments under assumptions about other economic variables specified by the observer. These specified assumptions will usually include some normative judgments concerning desirable policies-for example, the absence of direct controls over international transactions under conditions of full employment-but they need not. Observers may differ among themselves about which transactions should be "autonomous" and which "accommodating"; some may postulate positive targets for reserve changes, for example, while others may regard this as residual. $E$ will thus vary from observer to observer.

Let $\hat{E}$ be the desired, or target, value of $E$. On the argument presented above, the linguistically "natural" target value for $E$ is zero.

Define $B$ as an ex post measurement of imbalance in the country's international payments, for example, one of the concepts discussed in the preceding section and entered in Table 1. Given the country and time period, the value of $B$ can differ from the value of $E$ for three reasons. First, the $B$ in use may differ conceptually from the $E$ that various observers have in mind, although they may not be fully aware of that fact. Second, the specified economic assumptions underlying $E$ may be violated ex post, either as a result of deliberate changes in policy to cope with an expected imbalance in payments or as a result of the unforeseen impact of the international transactions themselves on other economic variables, such as the level of money incomes. Third, $B$ cannot capture exactly the autonomous transactions that make up $E$, since differences in motives do not correspond perfectly to any classification of observable transactions.

The difficulty arises when officials set $B=0$ as a target of public policy, having in mind $E=0$. The assumption that zero is the appropriate target for $E$ itself needs to be questioned. There may be times when prolonged payments surpluses or deficits serve to advance important economic objectives; but that is a matter which goes be- 
yond the issues of concern here. ${ }^{19}$ Even if we do accept $\hat{E}=0$, this is not the same as setting $B=0$ for the three reasons given above. Even under specified assumption about other economic variables there will generally be some difference between them, $B-E=u$, where $u$ represents the error in concept and measurement. Then $B=0$ implies $E=-u$, not $E=0$. To achieve the desired $E=0$, the target value for $B$ should be $u$, not zero.

An alternative to redefining the target is to redefine the target variable. Typically $u$ will vary, but to the extent that its variance is small and its mean value $\bar{u}$ is known, one might redefine the measure of imbalance as $B^{*}=B-\bar{u}$. Then directing public policy toward the target $B^{*}=0$ will imply a value of $E$ fairly close to zero. In this case moving the redefined measurement of imbalance to zero would guide the balance of payments near to equilibrium.

It is possible to discern in recent years a number of attempts to "redefine" the measurement of variables important to economic policy. Thus in 1962 the federal budget document for the first time emphasized the federal budget deficit as it appears in the national income accounts $\left(D^{*}\right)$ rather than the more traditional administrative budget deficit $(D)$, presumably in part on the grounds that setting $D^{*}=0$ would be less damaging to the economy than setting $D=$

${ }^{19}$ For an argument why U.S. payments deficits during the fifties contributed to world economic growth, see Cooper (1964).

More recently, Kindleberger (1965) has suggested another reason for expecting, and for tolerating, a U.S. deficit on the official settlements basis for some time to come. As financial intermediary for the world, the United States naturally borrows short and lends long. Not all foreigners will want to hold their growing liquid assets in dollars, so foreign central banks will acquire dollars in exchange for liquid domestic assets. Thus a free and efficient world capital market will produce U.S. deficits; attempts to eliminate these deficits run the risk of destroying a highly useful and mutually advantageous arrangement. In time, as European capital markets are improved, this financial intermediation will cease to take place through the United States; but that day is still far off.
0 , given the strong public sentiment for "balance" in the federal budget. Similarly, an attempt was made to shift public attention from the consumer price index $(P)$ to the wholesale price index $\left(P^{*}\right)$, presumably in part on the grounds that measurement biases in the consumer price index mean $P=0$ would require a depression of economic activity while $P^{*}=0$ is more consistent with other objectives and does not really violate the desire for price stability.

An alternative to these redefinitions of the target variables, as indicated above, is to get away from the notion that "equilibrium" or "stability" or "balance" means setting the target variable equal to zero. The attempt to shift public attention from the administrative federal budget to the national accounts budget was less successful than the effort to gain public acceptance for an administrative budget deficit when the U.S. economy is experiencing economic slack. This was the great educative value of the successful 1964 tax cut. Similarly, we have been treated to a number of statements by economists that an increase of, say, 2 per cent a year in the GNP deflator or the consumer price index is "tolerable" and does not represent "true" inflation. This approach brings these target variables more on a par with unemployment $(U)$, where we set $\hat{U}=k, k$ being some positive number (for example, 4 per cent of the civilian labor force) that is chosen pragmatically, taking into account any statistical weaknesses in the particular measure chosen.

Failure to distinguish between these alternative ways of approaching the same problem of setting targets for economic policy has clouded the attempt to define an appropriate measure of the balance of payments deficit or surplus. ${ }^{20}$ With the liquidity concept of imbalance in payments (line $D$ of Table 1), "restoring balance" is not the

${ }^{20}$ It is still better, of course, to look at the whole spectrum of international transactions in the light of one's objectives rather than to concentrate on any one balance. But this discussion accepts for argument's sake the popular assumption that there is a unique "balance." 
same as "restoring equilibrium" in the balance of payments if, as is the case for many observers, "equilibrium" contains some normative assumptions such as those specified by Nurkse. It would, on the contrary, give the world economy a substantial deflationary shock. This point is apparently well understood by the advocates of the liquidity concept, but it is not well understood by the public and by many officials. Lederer, for example, agrees with the Report (p. 101) that the principal purpose for a single measurement of the balance of payments is to indicate at a glance whether "things are 'going well or badly' or . . . getting better or worse" (Joint Economic Committee, 1965, p. 167). But he is willing to make this assessment against some estimate of secular growth in foreign demand for liquid dollar balances, an estimate that he concedes is difficult to make in practice and that he declines to attempt (ibid., p. 173). In terms of the notation above, Lederer is willing to change the numerical target from zero to some negative number, setting $\widehat{B}=k<0$ instead of $\hat{B}=0 .{ }^{21}$

The Bernstein report, in contrast, implicitly accepts a target of zero for the balance of payments, ${ }^{22}$ but attempts to redefine the measurement of imbalance so that this target makes economic sense. In terms of our notation, it has attempted to substitute $\hat{B}^{*}=0$ for $\hat{B}=0$, where $B^{*}$ represents the balance on official settlements and $B$ represents the measurement used by the Department of Commerce.

If one accepts the need for a single target variable, neither approach is exclusively

${ }^{21}$ The same point is urged strongly by George Chittenden, vice president of Morgan Guaranty Trust Co. (Joint Economic Committee, 1965, p. 84).

${ }^{22}$ See, for example, pp. 109-10 of the Report, quoted above. The question of policy targets is not discussed explicitly in the Report, except in a section (pp. 161-62) dealing with the important problem of maintaining consistency in the balance-of-payments concepts of all the world's trading countries, but Bernstein has stated his own view that with the official settlements concept "a normal deficit over a period of years would be about zero" (Joint Economic Committee, 1965, p. 289). right or wrong; so long as the alternative measurements are closely correlated, either of them can offer an equally appropriate guide to policy-makers..23 But Lederer is more likely to be right in principle and wrong in practice; right in principle because the official settlements balance does not capture purely compensatory transactions and therefore setting it equal to zero is not the appropriate balance-of-payments target for a reserve-currency country; wrong in practice because as long as the term "deficit" is applied to his liquidity concept, the public and both foreign and domestic policymakers will want to "eliminate" it. ${ }^{24}$ There is little question that the United States has had a serious balance-of-payments problem since 1958, but its magnitude has been greatly exaggerated by the published figures. As is too often the case where market psychology is involved, thinking the problem was large made it so. To many U.S. residents and foreigners, the task of eliminating a balance-of-payments deficit of $\$ 3.0$ billion seemed beyond the capability of modest moves, and some of the large volume of capital that left the United States during the 1960's undoubtedly reflected in part apprehension about the need for more drastic measures.

It would be desirable if an accounting deficit on the "liquidity concept" could be dissociated altogether from the notion of balance-of-payments disequilibrium. We should speak instead in terms of a positive target for growth in international liquidity,

${ }^{23}$ Although there are occasional deviations, quarter-by-quarter movements in the official settlements deficits were highly correlated $(+.78)$ with the deficit on a liquidity basis during the period 1959-64.

${ }^{24}$ In 1963 Senator Javits and Congressman Curtis introduced congressional resolutions that would have made balance-of-payments equilibrium-as then defined by the Department of Commerce-an objective of national policy. Luckily the resolution failed, but as if to indicate that the error is bipartisan, Secretary of the Treasury Fowler announced in late 1965 that the U.S. payments objective for 1966 was to be within $\$ 250$ million of balance-as defined by the liquidity concept. 
both public and private. Bar charts showing changes in the U.S. "liquidity position" should not drop from the zero line into the negative range, suggesting balance of payments sin, but should instead rise in the positive range, so as to invite an assessment of whether international liquidity seems to be growing too rapidly or too slowly. This target could be adjusted in level and in composition to what seems to be appropriate in some collective judgment, taking into account the foibles of measurement just as we do with the unemployment rate. Sustainability of the U.S.-supplied growth in international liquidity could then be gauged in terms of U.S. losses of gold and other reserve assets, not in terms of its liquidity position. The United States could continue its business of borrowing short and lending longboth out of current borrowings and out of domestic savings. If there is only one bank, there is no need to focus attention on its liquidity position. ${ }^{25}$ But there is need to worry about the stock of international money for the world economy as a whole.

But to the extent that contemporary attitudes concerning the balance of payments are too ingrained, to the extent that officials and the public do insist on one measure of the surplus or deficit, and to the extent that they think in terms of equating that measure to zero as an appropriate objective of public policy, the official settlements concept will offer a better guide to policy for the immediate future despite its defects, essentially because it moves above the line a major class of transactions that are largely if not wholly motivated by considerations of commercial interest. This is the frame of reference the Report evidently accepts as background for its recommendations.

\section{CONCLUSION}

This review has selected for discussion only a few of the many items examined in the Bernstein report, and it has focused on the few weaknesses of the Report at that. This should not obscure the very great contributions the Report has made in assessing thoroughly the balance-of-payments statistics of the United States, in presenting new figures and clarifying old ones, in discussing a variety of issues that bear importantly on interpretation of the statistics, ${ }^{26}$ and in making extensive and detailed recommendations for improvements in the quality of the statistics themselves and in their presentation to the public. It will sit for many years at the right hand of those who must work with the U.S. balance-ofpayments statistics.

\section{REFERENCES}

Cooper, Richard N. "Dollar Deficits and Postwar Economic Growth," Rev. Econ. and Statis., XLVI (May, 1964), 155-59.

Economic Report of the President. Washington: Government Printing Office, January, 1962. International Monetary Fund. Balance of Pay-

${ }^{25}$ This point has been made very eloquently by Fritz Machlup (1965).

If official liquidity is in the future provided collectively by some new reserve unit, with a resulting diminution in the role of the dollar in the growth of official reserves, then targeting the U.S. deficit on the official settlements basis at zero would be closer to the mark of payments equilibrium than it is today. The Report thus implicitly makes an optimistic appraisal of the chances for achieving international agreement on the creation of a new reserve asset! ments Yearbook, 1938, 1946, 1947. Washington: International Monetary Fund, 1949.

_- Balance of Payments Manual. 3d ed. Washington: International Monetary Fund, 1961.

Joint Economic Committee. The Balance of Payments Statistics. (Hearings before the Subcommittee on Economic Statistics of the Joint Economic Committee, 89th Congress.) Washington: Government Printing Office, June, 1965.

Kindleberger, Charles P. Balance-of-Payments Deficits and the International Market for

${ }^{26}$ Including seasonal adjustment of the payments figures, consistency of the balance-of-payments accounts with the national accounts, and consistency of the balance-of-payments accounts among countries. 
Liquidity. (Princeton Essays in International Finance, No. 46.) Princeton, N.J.: Princeton University, 1965.

Lary, Hal B. Problems of the United States as World Trader and Banker. New York: National Bureau of Economic Research, 1963.

Lederer, W. The Balance of Foreign Transactions: Problems of Definition and Measurement. (Special Paper in International Economics, No. 5.) Princeton, N.J.: Princeton University, 1963.

Machlup, Fritz. "The Cloakroom Rule of International Reserves: Reserve Creation and Resources Transfer," Q.J.E., LXXIX (August, 1965), 337-55.

Meade, James E. The Theory of International Economic Policy, Vol. I: The Balance of Payments. London: Oxford University Press, 1951.

National Bureau of Economic Research. $\mathrm{Na}$ tional Economic Accounts of the United States. (Hearings before the Subcommittee on Economic Statistics, Joint Economic Committee, 85th Congress, 1st Session, October 29-30, 1957.) Washington: Government Printing (office, 1957.
- "The Price Statistics of the Federal Government," in Government Price Statistics, Part I. (Hearings before the Subcommittee on Economic Statistics, Joint Economic Committee, 87th Congress, 1st Session, January 25,1961 .) Washington: Government Printing Office, 1961.

Nurkse, Ragnar. Conditions of International Monetary Equilibrium. (Princeton Essays in International Finance, No. 4.) Princeton, N.J.: Princeton University, 1945. (Reprinted in Howard S. Ellis and Lloyd A. Metzler [eds.], Readings in the Theory of International Trade [Philadelphia: Blakiston Co., 1950], pp. 3-34.)

President's Committee To Appraise Employment and Unemployment Statistics. Measuring Employment and Unemployment. Washington: Government Printing Office, 1962.

Review Committee for Balance of Payments Statistics. The Balance of Payments Statistics of the United States: A Review and Appraisal. (Report of the Review Committee for Balance of Payments Statistics.) Washington: Government Printing Office, 1965. ("Report.") 